\title{
Understanding of the Meaning of Native Customary Land (NCL) Boundaries and Ownership by the Bidayuh Community in Sarawak, Malaysia
}

\author{
Azima A.M1 \\ Novel Lyndon² \\ Mohd Shafiq Akmal ${ }^{3}$

\begin{abstract}
${ }^{1}$ Associate Professor, School of Social, Development and Environmental Studies, Faculty of Social Sciences and Humanities University Kebangsaan Malaysia, Bangi 43600,UKM, Selangor Malaysia azima@ukm.edu.my ${ }^{2}$ Associate Professor, School of Social, Development and Environmental Studies, Faculty of Social Sciences and Humanities University Kebangsaan Malaysia, Bangi 43600,UKM, Selangor Malaysia novellyndon@yahoo.com Kebangsaan Malaysia, Bangi 43600,UKM, Selangor Malaysia syafiq_ukm@yahoo.com
\end{abstract} \\ ${ }^{3}$ Research Officer, School of Social, Development and Environmental Studies, Faculty of Social Sciences and Humanities University
}

Doi:10.5901/mjss.2015.v6n5s1p342

\section{Abstract}

The issue of ownership needs for NCR land (Native Customary Rights Land) is a common matter that often becomes a dispute between communities and development agencies. The understanding of native communities and development agencies on the meaning of customary land boundaries are slightly different among each other. This issue arises because there is a need among the communities to defend their rights to ancestral or customary land. For a long time, customary communities consider the land as a symbol of the identity of their existence. Therefore, the focus of this study is to examine the meaning of customary land and land ownership among the Bidayuh community in the District of Serian, Sarawak from their own world-view. This needs to be given due attention in order to create an understanding towards the needs of land ownership and meaning of customary land boundaries in the context of the local community. Accordingly, a preliminary survey with the Bidayuh involved was carried out in Serian District. Collection of information via in-depth interviews with the NCR landowners in Serian district has generated some meaning to the needs of land boundaries and land ownership among them. Among these are those linked to the economic needs of subsistence, solidarity and the need for survival.

Keywords: NCR land, ownership, boundaries, customary land and Bidayuh community

\section{Introduction}

Most of the indigenous people do not have a written record of their menoa border. They only know of their boundaries orally such as bamboo clumps. Therefore, the natives understanding of the meaning of boundaries and ownership is something that has its own uniqueness. Common rules on boundaries and ownership of the land are understood by them through oral information inherited from one generation to another. Through the common rule, households in the community that first cleared the forest are guaranteed the rights to the land. Their rights to the land that they explored is indeed inherited and assured by the community which is then marked with natural borders known as 'lines' such as rivers, ridges and other permanent landmarks.

As such, the determination of the boundaries that define the area of pemakai menoa of a community with other communities is set according to the characteristics of its landscape like mountains, ridges, rivers, rocks or other signs such as tapang trees and clumps of bamboo. The umai land for example, includes all land that is planted as farms, gardens and orchards. Temuda on the other hand consists of land that has been cultivated with crops and also land that was formerly cultivated but is abandoned following the shifting cultivation cycle for the purpose of enrichment of the soil and forest conservation. Tembawai is the site of the old longhouse which has been abandoned but has a variety of fruit trees on it. The descendents of those who planted the crops are entitled to retain ownership of the plant but the land is community owned. Pulau Galau covers the forest area which is either wholly or partly surrounded by temuda or customary rights land that is deliberately maintained by individuals or the community through the generations and left uncleared, not farmed or worked on as resource for the community's domestic needs. Pulau Galau provides the long house community with necessities such as timber for building houses, making coffins and building boats, as well as forest, rattan and other forest products. At the same time, Pulau Galau can be owned by one or more longhouses. 
In terms of legislation, application and recognition of indigenous people's land boundaries and ownership by the society is not something foreign. This is because even before the existence of the Sarawak Land Code 1958, there was some early legislation that had been used as reference. Among them are Land Orders 1931, the Land Settlement Ordinance 1933, Application of Law Ordinance 1949, Land (Classification) Ordinance 1948, the Civil Law Act 1956 and presently, the Sarawak Land Code 1958. Generally, Sarawak Land Code 1958 emphasized that the claimant of ownership or interest must have a document of title in the form of grants, leases or other documents as proof of ownership or interest. However, there is provision for Customary Lands under Section 5 (2) which limits the use of these lands, among them:

- the felling of virgin forests and occupation of the cleared land;

- the planting of land with fruit trees ;

- the occupation of the cultivated land;

- the use of the land for a burial ground or shrine;

- the use of land for rights of way;

Many amendments have been made to the Land Code. For example, in 1994, amendments were approved to empower the minister in charge of land affairs to extinguish the native customary rights of land. In 1996, the responsibility was placed on the claimant to prove that he/she has customary rights to any land; this is because the land is considered as belonging to the State. In 1998, to allow for the acquisition of land for development purposes and so on, mechanisms for assessment and payment of compensation were put in place. The Land Code (Amendment) Ordinance 2000 has made several amendments among which involved the definition of 'native rights'. Accordingly, Section 7A (1) has detailed 'native rights' into three categories, namely:

- lawful rights to occupy pursuant to Section 5 (1) or (2);

- the rights and privileges of any Native Communal Reserve under Section 6 (1) ;

- $\quad$ rights within a kampung reserve (Section 7).

The 2000 amendment harmonized the processes and procedures relating to Native Customary Lands with the agencies involved in the context of alienated land and in relation to compensation for land acquired for development purposes. At the same time, the amendment in 2000 also drew attention to the registration of customary lands. These conditions correspond to the development needs of indigenous groups in Sarawak; however, it only involves indigenous or native communal land (Azima 2014).

\section{The Concept of Native Customary Land in Sarawak}

The importance of land which is a symbol or even the identity of each native group is the reason that their understanding in relation to the meaning of ownership and boundaries should be examined. This is because even though there are laws that recognize customary land rights, it was found that the stakeholders who have interests in development still have a different definition of native customary land. Under Section 2 (a) of the Sarawak Land Code, Native Customary Land $(\mathrm{NCL})$ is defined as "land where native customary rights (NCR) have been obtained communally or otherwise according to law before 1st January 1958 and is still legal tender". For the people in Sarawak who have settled on their land over the past few generations, their rights to the land therefore has been recognized by the law. However, Sarawak Land Code 1958 does not seem to give full recognition to the history of the natives with respect to the customs, traditions and practices of the community in setting the boundaries of communal land. Repeal of Section 5 (2) (f) provisioned in Sarawak Land Code 1958 has created even more challenges to the natives in defending their customary land rights. The disputes that beset have led many among the natives to take the decision to file their cases in court to obtain validation for their NCR demands. The existence of differences in interpretation of customary rights of the natives between the state authorities and the native communities have created numerous conflicts, subsequently leading to the problems relating to delays in processing the application and measurement of land in Sarawak. This situation eventually led to a conflict and stirred up feelings of dissatisfaction among the customary landowners. For example, a report prepared by a local newspaper on 27 May 2009 explained that the natives in Sarawak are trying to save the customary lands from being taken for development purposes. Amendments to Land Law Part 18 in 1997, which empowers the Superintendent of the Land and Survey Department to consolidate abandoned lands by declaring them as development areas, are considered to have affected the rights of the native or indigenous groups such as the Ibans, Orang Ulu and Bidayuhs, and even the Malays. This situation further clarifies the necessity to understand the meaning of customary land ownership and boundaries among the customary community. Thus, this paper will focus on the meaning of land ownership which was previously seen to have triggered several issues related to the rights of the people to customary land ownership. 


\section{Research Methodology}

Preliminary survey of the meaning of ownership and boundaries was conducted in five villages around Serian, Kuching Sarawak. The villages involved include Kg Mongkos, Tong Nibung, Sungai Aping, Sungai Keranji and Sungai Nibung. Views on the meaning of ownership and boundaries among the NCR landowners were obtained through the help of the Longhouse Chief or Tuai Rumah Panjang. Approximately 15 landowners have provided feedback in relation to the meaning of NCR land boundaries and ownership for the Bidayuh community in Sarawak. In-depth interviews with Bidayuh customary landowners enabled their knowledge of ownership and boundaries to be obtained. Emphasis was given by examining the elements that relate to the need for recognized land ownership, understanding of the meaning of ownership and boundaries, methods of determining ownership and boundaries and their implications.

\section{Study Area}

The Bidayuhs are the people who inhabit the southwest area of Sarawak, particularly the region of Serian, Kuching and in west Kalimantan. Most of them are Christians. The Bidayuhs can be broken down into four ethnic groups, namely:

1. Selakau/Lara (District of Lundu)

2. Jagoi/Singai (District of Bau)

3. Biatah (Sub-district of Padawan)

4. Bukar/Sadong (District of Serian)

5. Kuching Tengah / Bidayuh Baru / Bidayuh Moden (The Middle Area between Padawan and Bau).

In the olden days, the Bidayuh tribe lives in longhouses. Typically, the longhouse settlements of the Bidayuh tribe are located far inland and upland. This is for safety reasons in that it makes it difficult for them to be detected by the enemies. The structure of the Bidayuh longhouses is not much different from the structure of the Iban longhouses in Sarawak. The roof of the Bidayuh longhouse is made of thatched rumbia or sago leaves while the walls are made of bamboo. The floor of the house is made from wood or bamboo while the pillars are made of belian wood or timber.

The Bidayuh longhouse is divided into three parts, namely the main room, awah and tanju. The main room can be equated to the main hall of present day homes or residence. In this room, the Bidayuhs usually place personal items belonging to the family and their ancestors such as gongs, jars, pottery and so on. This room also serves as a place to sleep at night. Awah is the platform area outside the Bidayuh longhouse and is normally enclosed and roofed. It can be likened to the verandah of present day homes. The Bidayuhs carry out their daily activities such as weaving, chatting, and making farming equipment and so on in the 'awah'. The awah area will also be used for any religious ceremonies such as marriages, taboos and festivals such as the Gawai festival and so on. "Tanju" on the other hand is the outermost part of the Bidayuh longhouse. The tanju area is somewhat exposed and is normally not covered or roofed. Tanju is commonly used for drying the Bidayuh community's harvest such as rice, peppers, corns and so on.

\section{Result of the Study}

\subsection{Meaning of land boundaries and land ownership according to the Bidayuh People in Sarawak}

For the Bidayuhs, land can be divided into several types including family land, tanah pulau (forest reserve), tanah kampung (village land) and tanah makan (land for food). Normally the status of NCR land ownership which is inherited from generation to generation is known as hak kampong (village rights). Generally there are three types of NCR land for the Bidayuh community which are the NCR land (passed down from generation to generation), land which is measured or surveyed, and land which has been converted to agricultural land by the government. In general, the majority of the Bidayuh community inherited these NCR lands before the Japanese War. Its method of ownership is through inheritance from one generation to another which is legally recognized by the customary chief, namely the tuai rumah.

At the same time, for the Bidayuhs, determination of land ownership and land boundaries is decided by the community through the use of natural resources such as trees, rivers and so on. Among those commonly used as boundary 'lines' in the study area is the bamboo tree. Demarcation or marking of area boundaries by using the boundary lines of trees is not only known by the people in their group, but is also known by people in other ethnic groups. Hence, the role played by the customary chief or the tuai rumah and community leaders such as the Temenggung. This matter is very important in order to acknowledge the rights towards ownership of land that was explored, particularly for customary lands that have been owned since the time of the Japanese occupation. What is interesting for this NCR land ownership is that the land ownership is acknowledged to be permanent and non-tenured. 
The majority of customary landowners met gave positive views on the need for legitimate and recognized customary land ownership and boundaries. The majority of them thinks that determination of boundaries technically rather than orally or based on inheritance is absolutely indispensable. Technical determination of the boundaries and ownership is required to prevent boundary intrusion by land development agencies which are becoming more prevalent and widespread. This issue is clear from the views of the NCR landowners in the study area, including:

... "ownership and boundaries are essential to avoid intrusion ..."

In addition, legal or lawful recognition of ownership and boundaries will also facilitate them in obtaining grants of land ownership. This would subsequently facilitate dealings in developing their land with commercial activities such as oil palm plantations. In the meantime, there are those among them who realize that having clear ownership would enable them to get higher compensation if their land is taken for development purposes.

\subsection{Community's understanding of the meaning of land ownership and boundaries}

The issues that arise in relation to NCR land boundaries are associated with the problem of differences in interpretation on the rights of the Natives that is being adopted by the authorities and the native communities. This matter has created problems in the delimitation process when lands that are considered owned by the native communities are not recognised by the authorities and the boundaries prescribed do not cover or include the whole land owned by the native communities. This is because before the Sarawak Land Code 1958 was introduced, the native communities have already had menoa line (regional border) of their own. However, after January 1st 1958, the government has used certain characteristics for the determination of Section 5 (2). Hence, the need for the meaning of land ownership in the context of the Natives' understanding can be divided into subsistence, solidarity and survival needs. This would allow for a more holistic understanding in order to explain why the dispute associated with the existing law is challenged by the Natives.

\subsection{Land as subsistence requirement/needs}

Land is generally important as a source of livelihood of their subsistence economy. Land is important as an area for the people to look for food, for hunting and collecting forest products. In this matter, the land acts as an economic generator that depends on the subsistence activities of the Bidayuh community. The Bidayuh community uses their land for the purpose of survival in terms of economic aspect through their subsistence activities. As an example, they grow hill paddy on their family and village land. In addition, tanah pulau also contributes as their area to find sources of forest food such as forest fruits, rattan and so on. Accordingly, tanah pulau will ensure that the food source for the community will be inexhaustible or will not run out. In addition, the land will also become a place to live and a place for the community's daily activities. The respondents also agreed with the statement that land is essential to daily life in the social and cultural aspects. This is clear through the division of land types in the Bidayuh community where each one has its own function such as tanah pulau (anyone can use this land), tanah kampung or village land (known as village rights), tanah makan or land for food (owned by the relatives or tribe) and tanah keluarga or family land (owned by siblings). Accordingly, it is not surprising that land is said to be the "pulse or heart of the Bidayuh community and is very meaningful to them".

Even though now lands have been cultivated with commercial crops such as oil palm, the function and the division of land according to the understanding of the Bidayuh community is still maintained and continues to be practiced. Of particular importance in the context of their daily lives is the tanah pulau. This land demonstrates how the need to obtain forest resources becomes mutual use. For them, tanah pulau is very important in accommodating their daily needs through the activities of hunting and collecting forest produce.

\subsection{Land as a symbol of Bidayuh community's solidarity}

Land need as a tie between the races or tribes that share the land mutually reflects the existence of a strong bond of solidarity between them. This is obvious when customary landowners met did not deny that there indeed exists a deep and strong relationship between the Bidayuh community and their land. This is made clear when the majority of land owners interviewed agreed that land in the Bidayuh community is important and meaningful as a symbol of their identity. This situation is important to establish continuity from one generation to another. For that reason, it is not surprising if the community is always united in defending their land from intrusion either by private companies involved in the cultivation of oil palm or illegal logging. The feelings of the landowners in connection to the issue of intrusion that troubles the local 
community are clearly expressed in the grievance, which reads:

"... I'm worried about what the company is doing in our area, trespassing on my family land with bulldozers and pushing all the plants to open oil palm plantations. We've lost our land..."

The meaning that is shared mutually and collectively in the context of land ownership results in the relationship among the customary communities to become close and intimate. Often, the traditional lifestyle that is relevant to their knowledge and practice of the land leads to the sustainability of the community's relationship with the land. The unique tie that exists between the community and the land is the main pillar to the collective identity for their tribe. This is clear when the NCR landowners met acknowledged that

"...land is essential for maintaining the identity and culture that is continuous from one generation to another..."

\subsection{Land as a symbol of survival}

The Bidayuh community recognizes that land is an asset that is meaningful to them. Thus, it is not surprising if the land gives meaning to the religious and cultural ceremonies. As an example, before the pemakai menoa was created, the lban community for instance will celebrate a panggol menoa ceremony, which is a ceremony marking that the first clearing of virgin forest has been conducted and the area is habitable and can be cultivated for agriculture. The Bidayuh community considers the land as being entrusted to be preserved and passed down from generation to generation by the Bidayuh community. They also agreed that customs has determined that customary land is owned by the community forever. However, according to BRIMAS (1999), neglect and violations of the law is often done by state government which has resulted in many customary lands being converted into large-scale farms and also logging areas. According to Marcus (2008), the incessant opening of oil palm plantations has also led to natural resources such as rattan which is useful for crafts becoming extinct and the local community losing their side income from this activity. The impact is that the villagers are experiencing scarcity of land for their own use, such as for cultivation of paddy and other crops (Marcus 2008). If not treated seriously, definitely in the long run the culture and heritage that they have preserved all this while will disappear, consumed by profit oriented development.

The implication is that in the effort to defend their respective rights which are increasingly threatened, conflicts among the tribes emerge. Furthermore, there exist differences in the interpretation of the natives' customary rights that is being used by the authorities and the native community (SUHAKAM 2013). Inconsistent and narrow assessment coupled with competition for land and natural resources pose further challenges in the rights of the native people (Justin Vaz 2012). This situation proves the existence of a clash between customary law and the Sarawak Land law (Colchester 2008). Confusion begins to emerge when among the people, the customary land is recognized by the Native Court, but at the level of the State Land Code, customary land is only recognized when the courts recognize the letter or grants issued by the respective District Land Offices. This clarifies that there are various efforts undertaken to maintain their rights to customs. The community in this context should defend their rights to the land because since a long time land has been the symbol of their social capital. Hence, because of the land, the community has united to defend their rights.

\section{Discussion of the Meaning of Ownership Versus Delimitation}

The truth is obtaining land in Sarawak is not easy because there are about 1.5 million hectares of native customary rights land (Mohd Fuad, 2012). Thus, gaining recognition and respect for their rights over the land is something that is often championed by the community. Up until 1992, the endeavour of community mapping had been carried out through the efforts of several activists who tried to demarcate customary lands. Through the efforts carried out by BRIMAS via community-based mapping, it has apparently enabled customary land claims to be fully accepted by the court. Evidently, participatory mapping technique has become a powerful tool in empowering the community so that the government fairly recognize and respect their rights to their customary lands (Mark Bujang, 2008). However, the land surveyor ordinance in 2002 which only allows licensed surveyor to measure, authorize or sign any maps involving NCR land in Sarawak has made it difficult for the people to be jointly involved in the delimitation to prove that the lands are theirs (Fazilah Majid et al., 2011).

Therefore, understanding of the meaning of land ownership by the owners needs to be refined to avoid any conflict. Ownership need in the social context that takes into account the worldview of the local communities should be given attention. Furthermore, their rights to customary lands were recognized during the reign of the Brooke and the 
British colonial administration. It has never been repealed but the majority of these customary lands are not officially marked. The land tenure system that is unique and that has profound importance in their spiritual life makes it something interesting. Colchester (2008) traced the existence of a conflict between the traditional social organization and the modern social organization. In many ways, the community still wants to continue to defend the customary lands of their ancestors, while the administrators want to take the land for the purpose of development. The situation gets even more complicated when the community wishes to use their customary lands for subsistence farming while the administrators have larger plan which is to make the lands more productive by opening oil palm plantations (Rob and Patrick, 2011). Even though there is cooperation with the government, they are quite apprehensive when the lands are leased to private parties when the government is acting as a trustee for the community. They begin to be wary as they do not know how to regain their lands because of their status as owners that is not clear; moreover, the lands are registered in the name of the government.

To redefine or to reflect the true meaning of customary land rights, certain situations can be seen. Herperger (2010) suggests that understanding of the specific causes and consequences of land change is viewed by using the approach of actor oriented perspective. This model is influenced by three elements. These three elements include the forces, actors (landowners) and land changes. These three elements mutually react which ultimately affect changes in land use. The behaviour of the actors in decision-making is influenced by the forces that are related to policy needs and specific restrictions. Actors in this model are identified as having autonomy and motivation in influencing land use. Accordingly, actor reaction will lead to changes when questions related to "which forces are the most influential of changes in land use" arise or emerge.

In the context of the Bidayuh community's land ownership vs. boundaries, the actors i.e. the landowners play an important role. They have the autonomy in determining the boundaries of land in the proposition of tracing ownership. The autonomy of the landowners which has been recognized since the time of the Brooke becomes the motivation for them to defend ownership. Thus, understanding of the actors in their worldview context is important to avoid conflicts of ownership and boundaries. Ownership and determination of boundaries that applies local knowledge in determining the boundary lines is absolutely unique and only understood by the local community. Furthermore, Sarawak Land Laws do recognize Native Customary Land rights for the occupied land and territories. However, various attempts have been made to subvert the validity of customary land rights such as the State violating this law by issuing concessions, logging licenses and land grants for commercial farming. This is because for the purpose of customary land formation, grants should be issued. As long as grants are not issued, the land remains classified as state land. The Sarawak state government has also formulated a series of laws and amendments and regulations relating to land. This has automatically affected the land rights of the Native communities.

\section{Conclusion}

In summary, it can be concluded that the understanding and meaning of ownership and boundaries in the context of the community is something that is important. It is thus not surprising that in the motion of determining ownership and boundaries, the village chief, pemanca, longhouse chiefs or tuai rumah, penghulu and temenggung become the administrative organization that is very important in the context of customs. This situation explains that the natives or the indigenous people are not against development but they want their rights to be understood in their way. This is because even though most of them do not have written records of the boundaries and ownership, it has legitimate meaning according to their customs because the Mahkamah Penghulu (Native Court) acknowledges it. In 1939, the Brooke government issued Secretariat Circular No 12 to record the land boundaries officially. The records of proof of ownership are kept in the Boundary Book which stores the evidence that the NCR lands existed among which through the original physical markings of the menoa boundary formation (boundaries between one community and another).

\section{Acknowledgements}

The researcher would like to thank Ministry of Education of Malaysia under Fundamental Research Grant Scheme (FRGS) (Project Code: FRGS/1/2013/SS06/UKM/03/1) which enables smooth implementations of this research.

\section{References}

Azima Abdul Manaf, Novel Lyndon, Sivapalan Selvadurai, Mohd Yusof Hussain, Zaimah Ramli, SarmilaMd Sum, Suhana Saad, Mokhtar Jaafar and Fuad Mat Jali. (2014). Cabaran tranformasi Tanah NCR: satu keperluan terhadap metod Pemetaan 
Berpenglibatan (In Malays). Jurnal Geografia Vol 10 (1) : 110-117.

Borneo Resources Institute Malaysia (BRIMAS). (1999). Buku Kecil Tanah Adat Bumiputra dan Undang-Undang di Sarawak. Kuching: Sarawak (In Malays).

Dimbab Ngidang. (2007). Kuasa Pasaran ,Ruang Tanah Adat dan Pembangunan Tanah di Sarawak. International Seminar on Tanah Keterhakisan Sosial dan Ekologi:Pengalaman Malaysia dan Indonesia. Organised by Dewan Bahasa dan Pustaka and Institut Alam dan Tamadun Melayu (ATMA) Universiti Kebangsaan Malaysia. 4-5 December 2007 (In Malays).

Fazilah Majid Cooke, Su M. and Vaz, J. (2011). Making an informed choice a review of palm oil partnerships in Sabah and Sarawak, East Malaysia. Malaysia Palm Oil Study 25 May 2011.

Hersperger,A.M, M. Gennaio,P.H. Verburg and M. Burgi. (2010). Linking land change with driving forces and actors; four conceptual models. Journal Ecology and Society. Vol 15 (4): 1.

Justiz Vaz. (2012). An Analysis of international Law, National Legislation, Judgment and Institutions as they interrelate with territories and areas conserved by Indigenous Peoples and Local Communities. Report 15: Natural Justice Delhi.

Marcus, C. et al. (2008). Hak-hak tanah dan Pengembangan Perladangan Kelapa Sawit di Sarawak. Forest Peoples Programme dan Perkumpulan Sawit Watch (In Malays).

Mark Bujang. (2004). Malaysia's Case Study: A Community initiative: mapping Dayak's Customary Land in Sarawak. Borneo Resources Institute (BRIMAS).

Majid-Cooke F. (2003). Maps and counters maps: globalised imaginings and local realities of Sarawak's plantation agriculture. Journal of Southeast Asia Studies 34:265-284.

Mohd Fuad et al. (2012). Isu semasa dan persepsi belia terhadap politik dalam Pilihan Raya Umum Dewan Undangan Negeri Sarawak. Journal Geografia 8 : 138-148 (In Malays).

Rob C., and Patrick S. (2011). Shifting ground: renegotiating land rights and rural livelihoods in Sarawak, Malaysia. Journal Asia Pacific Viewpoint. Vol. 52 (2): 136-147.

Sarawak Land Code Amendment 1994. .(http://ms.wikipedia.org/wiki/Suku_Bidayuh).

Suruhanjaya Hak Asasi Manusia (SUHAKAM). (2013). Laporan Inkuiri Nasional Mengenai Hak Tanah Orang Asal/Asli. Published by Suruhajaya Hak Asasi Manusia: Kuala Lumpur (In Malays). 